\title{
INTERPERSONAL RELATIONS IN THE EDUCATIONAL AND MANUFACTURING ORGANIZATIONS
}

\begin{abstract}
MSc Jasmina Gocevska, Master of Arts in Human Resources in Entrepreneurship and Human Resources Development in Organizations, Skopje, Republic of Macedonia, E-mail: jasminagocevska@gmail.com Dr. Natasha Angeloska - Galevska, Faculty of Philosophy, University Ss. Cyril and Methodius, Skopje, Republic of Macedonia, E-mail: natasa@fzf.ukim.edu.mk
\end{abstract}

Received: May, 14.2015. Accepted: June, 01.2015. Original Article UDK 331.104 .2

\begin{abstract}
Success and efficiency in the working organizations today are based upon good communication and social relations between their employees. The importance of these processes is visible in the use of modern techniques of communicating and the support of team building and team work in organizations. Communication and social climate is a topic that is contemporary and interesting to explore. Therefore, this research is focused on processes of communication and social interaction in the educational and manufacturing working environments. Research data were gathered with survey on a sample of 121 workers from two educational and two manufacturing working organizations. Two types of questionnaires were used: a questionnaire by Richard L. Daft (2001) on the communication issue and so-called WES Work Environment Scale concerning social interaction. Data were analysed with statistical procedures of descriptive statistics (frequencies, percentage, mean and standard deviation) and inferential statistics (t-test) for testing of hypotheses.

Based upon this analysis came the conclusion that there is a difference in the degree of development of these important personal skills. The results show that the workers in the educational working organizations have a greater ability to communicate and interact compared to those in the manufacturing organizations.

This research is meant to be a base for conclusions that came by information gathered in these two kinds of organizations so that the insight could lead further research in other types of organizations.
\end{abstract}

Keyword: Social interaction, Communication, Working organisations.

\section{INTRODUCTION}

Everyday's life is mainly associated with the needs that individuals fulfill within

Corresponding Author

Dr. Natasha Angeloska Galevska, Faculty of Philosophy, University Ss. Cyril and Methodius, Skopje

E-mail: natasa@fzf.ukim.edu.mk different types of organizations. Beginning with the dependence from the family, further on with institutions like school, working organizations and different kinds of associations, the individual becomes a part of the wider society, gains its' part in it and fulfills its' own human needs.

Every human being is a social being, and during its' life is in interaction with the other social entities. Therefore it is necessary people to possess ability to maintain good relations with the others, that includes good social interaction and good communication.

From the aspect of modern living the ability for good social interaction and communication has the leading role. Another interesting fact is that today's way of organization work needs coordination of teams, that are consisted of collaborators with different professional profiles putting in first line high level of communication. Common goals and grow of organizations can be achieved with good communication and less misunderstanding. The good relations are especially important for coordination of the organization, as a whole and between different levels of the organizational hierarchy. They can be also a precondition for the solutions for potential conflicts, and especially for their prevention.

Communication is the most basic mean of social interaction and these skills are mostly necessary in the work of the teams. In order to achieve the right effect, it is important message to be well transmitted to the recipient. The correct comprehension of the message is the bases of the good organizational work. As long there is good communication in the organization and good social interaction, there is a strong possibility for strong organizational work.

The importance of the issue motivated us to explore this phenomenon and to verify some hypotheses related to social interaction 
and communication in the manufacturing and educational organizations. In broader context, research is associated with various aspects of the human resources management as well.

\section{MATERIALS AND METHODS}

The research aims to determine the difference between the assessment of the working environment and the personal view of the communication skills of the employees in manufacturing and educational working organizations. Empiric exploration of the differences can lead further to developing ways for their improvement.

Research problem was mainly focused on the social interaction and communication between the employees in the manufacturing and educational working organizations.

Social interaction is associated with the relations between different kind of social entities: people, little groups, organizations, different social institutions, large social groups, global social communities, and different kinds of associations of people.

Communication is the basic and most common shape of social interaction.

The aim of the research is to define how the employees assess their working environment and to determine whether there is a difference in the processes of social interaction and communication between the employees in the manufacturing and educational working environments.

According to the strategy that is used, the research can be defined as contemporary, comparative, inter-disciplinary, transversal, and quantitative. following:

Objectives of the research are the

1. Determination of the difference in the assessment of the working environment by the employees in the manufacturing and educational working organizations.

2. Determination of the difference in the assessment of the working environment by the employees in the manufacturing and educational working organizations having in consideration the gender.

3. Determination of the difference in the assessment of the working environment by the employees in the manufacturing and educational working organizations depending on their working experience.
4. Determination of the difference in the assessment of the working environment by the employees in the manufacturing and educational working organizations having in consideration the level of education.

5. Determination of the difference in the personal sense for communication by the employees in the manufacturing and educational working organizations.

6. Determination of the difference in the personal sense for communication by the employees in the manufacturing and educational working organizations having in consideration the gender.

7. Determination of the difference in the personal sense for communication by the employees in the manufacturing and educational working organizations having in consideration the working experience.

8. Determination of the difference in the personal sense for communication by the employees in the manufacturing and educational working organizations having in consideration the level of education.

General hypotheses:

1. There is a significant difference in the assessment of the working environment by the employees in the manufacturing and educational working organizations.

2. There is a significant difference in the personal sense for communication by the employees in the manufacturing and educational working organizations.

Sub hypotheses:

1. There is a significant difference in the assessment of the working environment by the employees in the manufacturing and educational working organizations having in consideration the gender.

2. There is a significant difference in the personal sense for communication by the employees in the manufacturing and educational working organizations having in consideration the gender.

3. There is a significant difference in the assessment of the working environment by the employees in the manufacturing and educational working organizations 
having in consideration the working experience.

4. There is a significant difference in the personal sense for communication by the employees in the manufacturing and educational working organizations having in consideration the working experience.

5. There is a significant difference in the assessment of the working environment by the employees in the manufacturing and educational working organizations having in consideration the level of education.

6. There is a significant difference in the personal sense for communication by the employees in the manufacturing and educational working organizations having in consideration the level of education.

Relevant variables of the research are: the type of organizations, the gender, the working experience and the level of education.

Dependent variables are: social interaction and communication.

Regarding to the human resource management it is important to maintain high level of social interaction and communication, in order to develop good work atmosphere. It is very important to find more adequate ways to keep the level high. Therefore in this work the focus is on exploring this field using scientific methods. We used descriptive, comparative and correlative research methods. Data were collected with use of scales and questionnaires:

- For the assessment of the personal sense for communication we used five-level Likert scale by Richard L. Daft. The score range is from 24 to 120 with the average score of 72 .

- For the assessment of the working environment we used WES scale of the working environment (Moos, 1994) with the subscale for IWR assessment (Index on Work Relations - IWR) that encompasses an involvement, peer cohesion and supervisor support. The range of the IWR score is from 1 to 27 with the average score of 14 .

\section{Research sample}

Population of the research are the employees from manufacturing and educational organizations The sample is consisted of 121 employees from two manufacturing and two educational working organizations from
Skopje, Republic of Macedonia (around 30 employees from each organization).

\section{Data analyses}

The statistical data that are analyzed in this study are attributive and numerical.

- Attributive: field of work, gender, level of education.

- Numerical: working experience.

The statistical values used in the evaluation are of the descriptive and inferential statistics, such as the distribution of frequencies, percentage, arithmetical mean, standard deviation, standard error of arithmetical mean and $\mathrm{t}$ - test for the testing of the hypotheses.

\section{Organisation and Procedure}

This research is quantitative and is completed in seven phases:

1. Identification, definition and specification of the problem.

2. Designing a research plan.

3. Implementation of techniques for data collection.

4. Testing the hypotheses.

5. Analyzing and interpreting the results and making conclusions.

6. Writing a report.

7. The new conclusions are a contribution for scientific growth.

\section{RESULTS}

The research sample has the following characteristics:

- The number of male employees was larger in the manufacturing organizations compared to the female employees .

- The number of female employees in the educational organizations was larger compared to the male employees.

- The number of employees that have bigger working experience was larger in the manufacturing organizations compared to the educational organizations.

- The number of employees that had a higher level of education was larger in the educational organizations compared to the manufacturing ones. 
As for the scores from the questionnaires, it was evident that:

- The assessment of the working environment was on a higher level among the employees in the educational working organizations compared to those in the manufacturing ones.

- The personal sense for communication was on a higher level among the employees in the educational working organizations compared to those in the manufacturing ones.

- The lowest score for the assessment of the working environment was with the employees in the manufacturing organizations.

- The lowest score for the personal sense for communication was with the employees in the educational organizations.

The results also show that:

- $52,3 \%$ of the employees in the manufacturing organizations have a score above the average concerning the assessment of the working environment.

- $64,3 \%$ of the employees in the educational organizations have a score above the average when the assessment of the working environment is concerned.

- $75,4 \%$ of the employees in the manufacturing organizations have a score higher than the average concerning the personal sense for communication.

- $87,5 \%$ of the employees in the educational organizations have a score higher than the average when the personal sense for communication is concerned.

As for the research hypotheses, the conclusion is that both of the main hypotheses can be approved and there is a significant difference in the assessment of the working environment and the personal sense for communication between the employees in the manufacturing and educational working environments.

This study also involved testing of the sub hypotheses, and statistical analyses results with following conclusions:

- There is not a significant difference in the assessment of the working environment by the employees in the manufacturing and educational working organizations.
Table 1. Significance of the difference in the assessment of the working environment by the employees in the manufacturing and educational working organizations

\begin{tabular}{lccccc}
\hline $\begin{array}{l}\text { Type of } \\
\text { organization }\end{array}$ & $\mathrm{N}$ & $\mathrm{M}$ & $\mathrm{SD}$ & $\mathrm{t}$ & $\mathrm{p}$ \\
\cline { 1 - 4 } Manufacturing & 65 & 14,63 & 4,68 & 1,32 & $>0.01$ \\
\cline { 1 - 4 } Educational & 56 & 15,87 & 5,62 & & \\
\hline
\end{tabular}

- There is a significant difference in the personal sense for communication between the employees in the manufacturing and educational working organizations.

Table 2. Significance of the difference in the personal sense for communication between the employees in the manufacturing and educational working organizations

\begin{tabular}{|c|c|c|c|c|c|}
\hline $\begin{array}{l}\text { Type of } \\
\text { organization }\end{array}$ & $\mathrm{N}$ & M & $\mathrm{SD}$ & $\mathrm{t}$ & $\mathrm{p}$ \\
\hline Manufacturing & 65 & 80,58 & 13,72 & \multirow{2}{*}{3,35} & \multirow{2}{*}{$<0.01$} \\
\hline Educational & 56 & 90,37 & 18,08 & & \\
\hline
\end{tabular}

- There is not a significant difference in the assessment of the working environment by the employees in the manufacturing and educational working organizations, depending on a gender.

Table 3. Significance of the difference in the assessment of the working environment by the employees in the manufacturing and educational working organizations, depending on the gender

\begin{tabular}{lccccc}
\hline Gender & $\mathrm{N}$ & $\mathrm{M}$ & $\mathrm{SD}$ & $\mathrm{t}$ & $\mathrm{p}$ \\
\hline Women & 52 & 14,86 & 4,94 & \multirow{2}{*}{$-1,19$} & $>0.01$ \\
\cline { 1 - 3 } Men & 48 & 16,04 & 4,9 & &
\end{tabular}

- The analyses shows that there is not a significant difference in the personal sense for communication between the employees in the manufacturing and educational working organizations, depending on a gender.

Table 4. Significance of the difference in the personal sense for communication between the employees in the manufacturing and educational working organizations, depending on the gender

\begin{tabular}{lccccc}
\hline Gender & $\mathrm{N}$ & $\mathrm{M}$ & $\mathrm{SD}$ & $\mathrm{t}$ & $\mathrm{p}$ \\
\cline { 1 - 3 } Women & 52 & 85,82 & 15,84 & \multirow{2}{*}{0,09} & $>0.01$ \\
\cline { 1 - 3 } Men & 48 & 85,52 & 17,07 & & \\
\hline
\end{tabular}

- There is not a significant difference in the assessment of the working environment by the employees in the manufacturing and educational 
working organizations, as far as the working experience is concerned.

Table 5. Significance of the difference in the assessment of the working environment by the employees in the manufacturing and educational working organizations, as far as the working experience is concerned

\begin{tabular}{lccccc}
\hline $\begin{array}{l}\text { Working } \\
\text { experience }\end{array}$ & $\mathrm{N}$ & $\mathrm{M}$ & $\mathrm{SD}$ & $\mathrm{t}$ & $\mathrm{p}$ \\
\cline { 1 - 4 } Less & 62 & 15,47 & 4,89 & \multirow{2}{*}{0,42} & $>0.01$ \\
\cline { 1 - 4 } More & 50 & 15,04 & 5,83 & &
\end{tabular}

- The analyses shows that there is not a significant difference in the personal sense for communication between the employees in the manufacturing and educational working organizations, as far as working experience is concerned.

Table 6. Significance of the difference in the personal sense for communication between the employees in the manufacturing and educational working organizations, as far as working experience is concerned

\begin{tabular}{lccccc}
\hline $\begin{array}{l}\text { Working } \\
\text { experience }\end{array}$ & $\mathrm{N}$ & $\mathrm{M}$ & $\mathrm{SD}$ & $\mathrm{t}$ & $\mathrm{p}$ \\
\cline { 1 - 4 } Less & 62 & 88,14 & 15,33 & \multirow{2}{*}{1,84} & $>0.01$ \\
\cline { 1 - 5 } More & 50 & 82,6 & 16,54 & &
\end{tabular}

- The analyses shows that there is not a significant difference in the assessment of the working environment by the employees in the manufacturing and educational working organizations depending on their level of education.

Table 7. Significance of the difference in the assessment of the working environment by the employees in the manufacturing and educational working organizations, depending on their level of education

\begin{tabular}{lccccc}
\hline $\begin{array}{l}\text { Level of } \\
\text { education }\end{array}$ & $\mathrm{N}$ & $\mathrm{M}$ & $\mathrm{SD}$ & $\mathrm{t}$ & $\mathrm{p}$ \\
\cline { 1 - 3 } Lower & 67 & 14,62 & 4,86 & \multirow{2}{*}{$-1,22$} & $>0.01$ \\
\cline { 1 - 4 } Higher & 47 & 15,83 & 5,63 & & \\
\hline
\end{tabular}

- The analyses shows that there is a significant difference in the personal sense for communication between the employees in the manufacturing and educational working organizations, as far as the level of education is concerned.
Table 8. Significance of the difference in the personal sense for communication between the employees in the manufacturing and educational working organizations, depending on their level of education

\begin{tabular}{|c|c|c|c|c|c|}
\hline $\begin{array}{l}\text { Level of } \\
\text { education }\end{array}$ & $\mathrm{N}$ & M & SD & $\mathrm{t}$ & $\mathrm{p}$ \\
\hline Lower & 67 & 79,97 & 15,75 & \multirow{2}{*}{$-4,27$} & \multirow{2}{*}{$<0.01$} \\
\hline Higher & 47 & 92,42 & 15,12 & & \\
\hline
\end{tabular}

\section{DISCUSSION}

In this research study we explored the differences between the assessment of the working environment and the personal sense for communication of the employees in the manufacturing and educational working organizations as a basis to find ways to develop more efficient ways and improvement of these processes in the organizations.

This empiric results point out that a large number of employees both in educational and manufacturing organizations have a high level of personal sense of communication.

Related to the assessment of the working environment, a large percentage of employees in the educational organizations are satisfied with it, compared to the smaller percentage in the manufacturing organizations.

These results point out to the correlation between the communication skills and social interaction. As much as the individual communicates better with the others, it is most likely that he/she is able to preserve good relations with them.

This research shows, further on, that processes of communication and social interaction are different between the employees in the manufacturing and educational organizations, that confirms the general hypotheses of research. These differences are based on the nature of the profession and specifics of work in these different kind of organizations, whether it has more to do with individual or team work. Comparing these results with other relevant research on global and local level shows that some conclusions correspond to other and some differ.

As far as this exploration being done in Macedonia, it shows that the conclusions differ from an organization to organization. In one case the individual work was more important because it involved putting pieces together. But in another organization, the team work between different types of professionals was more important. 
The research in educational organizations show that the social climate and positive assessment of the working environment is present amongst all of them due to the autonomy orientation towards work and low work pressure. The results in different educational organizations are similar. The personal sense for communication is an individual characteristic that is in correlation with the social climate and in environments where the communication is on a higher level there is more productivity shown in the research of Mayo. Research in educational organizations in Macedonia also confirm that variations in social climate affect variations in work satisfaction. (Sardzoska, 1997).

The results of our study also point to the fact that the employees in the educational organizations possess good communication skills, but there is always need and room for their improvement. More frequent contacts in the sphere of informal interaction could contribute to socialization of employees outside of work. That way the group will be able to communicate better and to come to solutions that are common for the employees inside the organizations.

In the manufacturing organizations the personal sense for communication is on a high level but there is a lower satisfaction with the working environment. There is a more expressed informal communication that results with better social interaction.

It is important employees to be involved in the communication as much as possible. Meetings should be done daily, weekly or monthly, and face-in-face. In this way we reduce the possibilities for conflicts and misunderstandings. Implementing the new techniques for communicating, supporting team work and spirit are efficient tolls and show good results in overcoming of located problems in this field. Team work is the bases for the survival of the organizations today and it is a responsibility and challenge for the managers of human resources.

\section{CONCLUSION}

This research is focused on relations between employees in working and manufacturing organizations analyzed from different aspects. Until now, this topic has been explored by eminent researchers, beginning with the Hawthorne studies conducted by Elton Mayo (Roethlisberger F.J., Dickson, W.J , 2003), later on with Hertzberg research, scientific work of the researchers in the Tavistock Institute of Human Relations in UK, as well as researchers in Macedonia. Results mainly confirm that good communication and social interaction are in favor of productivity.

Results of our study point out that there is a significant difference between the personal sense for communicating and assessment of the working environment of the employees in the manufacturing and educational organizations. Testing of the sub hypothesis confirmed that there is a significant difference in the personal sense for communication between the employees in the manufacturing and educational organizations, concerning the level of education. As shown in this work, the employees in the educational organization have better skills in communicating and interaction than those in manufacturing organizations, which is in correlation with the nature of their professional work.

The study gave possibility for the workers to express their attitudes but also for the employers to have an insight in their workers' opinions. Based on the results, managers can plan use of new techniques for improving the communication and social climate inside the organizations. Beside the syndicates, it is up to the HRs to manage the interest of the employees and the employers. That means that during the selection process the candidates must have strong abilities to communicate and interact. Communication and interaction are the main factors in the functioning of organizations and the future should be focused on their improvement and growth.

\section{Conflict of interests}

Authors declare no conflict of interest.

\section{REFERENCES}

Daft, R. L., \& Noe, R. A. (2001). Organization behavior. Orland, FL: Harcourt College.

Moos, R. H. (1994). Work environment scale manual. Consulting Psychologists Press.

Roethlisberger, F. J., \& Dickson, W. J. (2003). Management and the Worker (Vol. 5). Psychology Press.

Сарџоска, Е. (1997). Социјалната клима и работното задоволство во училишна работна средина. Годишен зборник на Филозофски факултет, Скопје: Филозофски факултет. 